\title{
The Multicultural Education Paradigm Pattern: A Case Study in Muhammadiyah Junior High School in Palangka Raya, Indonesia
}

The problems and the aim of the study. Indonesian society has problems of cultural disparities, occupation movements from different cultural backgrounds, and differences in conceptual understanding and application that give rise to the spirit of diversity in the fields that build multicultural education. This proposed study to identify fields that build multicultural education in Muhammadiyah Junior High Schools through a description of student interactions in these fields.

Research Methods. Quantitative approach with a descriptive analysis. Sampling used a sample quota. The sampling included 29 students of grade VIII Muhammadiyah Junior High School in Palangka Raya and is the only Junior High School in the Muhammadiyah organization.

Result. This research reveals religion as a way of learning and interacting in their daily life $(80 \%=$ Sure until Very Sure). Gender, namely feeling more comfortable hanging out with friends of different sexes but still in accordance with religious rules ( $57 \%=$ Sure until Very Sure). Students in socializing. Ethnic, namely respecting friends who are different from their region of origin so that they are able to mingle in social relationships $(75 \%=$ Sure until Very Sure). Racial, namely students can interact with friends who are less handsome or beautiful $(61 \%=$ Sure until Very Sure). Cultural indicators, namely students value friends who are not smart and do not get along well $(97 \%=$ Sure until Very Sure). Social class, namely students choose rich friends and parents who have positions in learning and social groups $(54 \%=$ Sure until Very Sure). But not all can implement according to the theory of multicultural education because each individual has their own thoughts and understanding of diversity $(20 \%-46 \%=$ Less Sure to Not Sure).

Conclusion. Multicultural education at Muhammadiyah Junior High School Palangka Raya was revealed to be able to be adopted by students so that the school still maintained the characteristics of Muhammadiyah but there were still students who were unable to adapt and construct.

Keywords: Patterns, Multicultural Education, Thoughts, Ability, Learning, Interaction, Fields of Multicultural Education, Junior High School, Muhammadiyah

\section{For Reference:}

Noor, A. F., Sonedi, Azman, M. N. A., Khunaifi, A. R., Dwiningrum, S. I. A., \& Haryanto (2021). The Multicultural Education Paradigm Pattern: A Case Study in Muhammadiyah Junior High School in Palangka Raya, Indonesia. Perspektivy nauki i obrazovania - Perspectives of Science and Education, 52 (4), 297-310. doi: 10.32744/pse.2021.4.19 
he phenomenon of millennial community life in the era of globalization in industry 4.0, namely the density of activities of children, adolescents, and parents spending more time on the internet and using social media so that interaction between individuals is reduced. This incident is a cultural leap from various fields of religion, gender, race, ethnicity, culture, and social structure in the sense that humans experience a cultural lag or cultural gap proposed by William Ogburn [56; 39, p. 23-24].

Central Kalimantan, with its capital Palangka Raya, is one of the provinces in Indonesia, in habited by the three largest ethnic groups, namely: the Dayak (46.62\%), Javanese (21.67\%), and Banjar (21.03\%), there are also Malays and Madura is concluded to have assimilated with the Dayak tribes [16]. This has an impact on the diversity of population development identities of junior high school-aged children (12-15 years or early adolescents). Therefore, education aimed at overcoming differences must be developed based on the situation of diversity in student identities [50; 69].

The spirit of the diversity of identities of students who come from transmigration and urbanization $[44 ; 28 ; 5 ; 30]$ translated in multicultural education in Central Kalimantan which is incorporated into the learning process of students in the school in accordance [17] are as follows: local language and literature, local arts, skills, and local crafts, customs and customary law, local history, local Technology, Natural Environment/Ecosystem, traditional medicines, traditional cuisine, traditional clothing, traditional sports, and the value of local culture in a global perspective [58].

Multicultural education focuses on deepening behavior that is formed from thorough and in-depth experiences of religion, gender, race, ethnicity, culture, and social structures [71, p. 41; 39, p. 105-107; 43]. In French junior high schools, students who are taught general knowledge have not yet focused on certain areas but they are within the rules of equality in religion, gender, race, ethnicity, culture, and social structure without exception, religion is considered to only apply to the private environment, does not apply to the common environment [63].

The next phenomenon, differences in conceptual perceptions with the application still hinder the progress of multicultural education, and there is a large gap between the theory, definition, and practice of multicultural education in parents, teacher education programs, and school districts in the Central Coast of California [23, p. 50; 37].

The need for early adolescents (junior high school students) in learning to understand the theory and application of cultural differences is a transition period from childhood to adolescence. Cultural diversity is a challenge addition to be overcome, educators must understand the richness of the cultural diversity of Indonesia, especially Palangka Raya, Central Kalimantan $[41 ; 62 ; 46]$.

\section{Materials and methods}

This research uses a quantitative approach with a descriptive analysis, namely giving a description based on indicators of multicultural education, namely religion, gender, ethnicity, race, culture, and social class [35, p. 61-62; 65, P. 216-217; 21, p. 217-218]. The place of research is Muhammadiyah Junior High School because the only in Palangka 
Raya which is under Muhammadiyah organization. Sampling using a purposive sample. The sampling included 29 students of grade VIII (fifteen female and fourteen male). Multicultural education indicators, namely religion, gender, ethnicity, race, culture, and social class focus on praxis in everyday life both at home and at school [65, p. 224; 59, p. 215-216; 21, p. 211].

Collecting data using observations, documentation, and questionnaire. The data was also strengthened through a questionnaire with a Likert scale with range 1-5 point, point $1=$ less sure; point $2=$ not sure; point $3=$ sure enough; point $4=$ sure; and point $5=$ very confident as presented in Table 1 [61, p. 12-16].

Table 1

The comparison definition 5-point likert scale

\begin{tabular}{|c|c|}
\hline Intensity of Importance 5-Point & Likert Scale Definiton \\
\hline 1 & Not Sure \\
\hline 2 & Less Sure \\
\hline 3 & Sure Enough \\
\hline 4 & Sure \\
\hline 5 & Very Sure \\
\hline
\end{tabular}

The validation of the questionnaire was carried out through content verification through three experts, these three experts worked to check and provide comments. These three experts verified the content of the questions, the sentences used in asking, and the suitability of the questions with the grid. The results of the verification are still using 6 fields of multicultural education with 18 questions and correcting sentences to be simple so that students can easily understand them. The three experts are as follows (Table 2).

Table 2

Background of validators

\begin{tabular}{|c|c|l|l|}
\hline Validator & Gender & \multicolumn{1}{|c|}{ Background } & \multicolumn{1}{|c|}{ Experienced and Position } \\
\hline V1 & Male & $\begin{array}{l}\text { Doctoral, Lecturer of Faculty of Teacher } \\
\text { Training and Education, Counseling Guidance } \\
\text { Department. Has experience and expertise in } \\
\text { the fields of religion, general education, and } \\
\text { multicultural education (include Citizenship } \\
\text { Education). }\end{array}$ & $\begin{array}{l}\text { More than 20 years and former Head of } \\
\text { the higher education quality development } \\
\text { planning agency and dean of Faculty of } \\
\text { Teacher Training and Education; currently } \\
\text { serves as Head of the Student Affairs and } \\
\text { Alumni Bureau. }\end{array}$ \\
\hline V2 & Male & $\begin{array}{l}\text { Lecturer of Faculty of Teacher Training } \\
\text { and Education, Primary Teacher Education } \\
\text { Department. Has experience and expertise in } \\
\text { the fields of Indonesian language courses. }\end{array}$ & $\begin{array}{l}\text { More than 5 years and serves as Head of the } \\
\text { Learning Laboratory. }\end{array}$ \\
\hline V3 & Female & $\begin{array}{l}\text { Lecturer of Faculty of Teacher Training and } \\
\text { Education, Counseling Guidance Department. } \\
\text { Has experience and expertise in the fields of } \\
\text { psychology. }\end{array}$ & $\begin{array}{l}\text { More than 8 years and serves as quality } \\
\text { control group Coordinator of Quality Control } \\
\text { Group of Faculty of Teacher Training and } \\
\text { Education and Professional Psychologist. }\end{array}$ \\
\hline
\end{tabular}

In accordance with the question guide grid that has been set based on theory, which are shown in Table 3. 
Table 3

List of 18 questioner for 6 criteria of multicultural education

\begin{tabular}{|c|c|c|l|}
\hline $\begin{array}{c}\text { Variable } \\
\text { Eulticultural }\end{array}$ & No. & Indicators & Rescription \\
\hline & 2 & Gender & $\begin{array}{l}\text { 1. Interact and make decisions based on universal religious values } \\
\text { 2. A person's view of life } \\
\text { 3. Implementation of the value of compassion and tolerance } \\
\text { 4. Appreciate gender differences } \\
\text { 6. Cooperate in activities }\end{array}$ \\
\hline & 3 & Region & $\begin{array}{l}\text { 7. Respect for differences in regional origin } \\
\text { 8. Social and respect } \\
\text { 9. In groups }\end{array}$ \\
\hline & 5 & Race & $\begin{array}{l}\text { 10. Togetherness } \\
\text { 11. Make friends and appreciation } \\
\text { 12. Respect differences in physical form }\end{array}$ \\
\hline & 6 & Cultural & $\begin{array}{l}\text { 13. Ability to think according to positive cultural values } \\
\text { 14. Helps in activities } \\
\text { 15. Respect when interacting }\end{array}$ \\
\hline & Social Strata & $\begin{array}{l}\text { 16. Appreciate differences in economic status } \\
\text { 17. Interact regardless of position } \\
\text { 18. Happiness in groups }\end{array}$ \\
\hline
\end{tabular}

Each indicator has 3 questions, so the total number of questions for all indicators is 18 questions. 18 questions were obtained from the results of the article analysis and the literature review.

Table 4

Indicators of multicultural education of junior high school student

\begin{tabular}{|l|c|c|c|c|c|}
\hline & N & Minimum & Maximum & Mean & Std. Deviation \\
\hline Religion_1A & 29 & 3,00 & 5,00 & 4,7931 &, 49130 \\
\hline Religion_2B & 29 & 1,00 & 5,00 & 2,4483 & 1,08845 \\
\hline Religion_3C & 29 & 3,00 & 5,00 & 4,6207 &, 62185 \\
\hline Gender_1A & 29 & 1,00 & 3,00 & 1,4483 &, 73612 \\
\hline Gender_2B & 29 & 1,00 & 3,00 & 1,5517 &, 82748 \\
\hline Gender_3C & 29 & 2,00 & 5,00 & 4,0690 &, 84223 \\
\hline Region_1A & 29 & 3,00 & 5,00 & 4,6897 &, 54139 \\
\hline Region_2B & 29 & 3,00 & 5,00 & 4,5172 &, 63362 \\
\hline Region_3C & 29 & 1,00 & 5,00 & 1,9310 & 1,03272 \\
\hline Race_1A & 29 & 1,00 & 5,00 & 2,5172 & 1,32613 \\
\hline Race_2B & 29 & 1,00 & 5,00 & 2,6897 & 1,25651 \\
\hline Race_3C & 29 & 2,00 & 5,00 & 4,4483 &, 68589 \\
\hline Cultural_1A & 29 & 1,00 & 5,00 & 3,9310 & 1,13172 \\
\hline Cultural_2B & 29 & 3,00 & 5,00 & 4,1724 &, 75918 \\
\hline Cultutral_3C & 29 & 2,00 & 5,00 & 4,0690 &, 84223 \\
\hline SocialStrata_1A & 29 & 3,00 & 5,00 & 3,9310 &, 70361 \\
\hline SocialStrata_2B & 29 & 1,00 & 5,00 & 2,4828 & 1,12188 \\
\hline SocialStrata_3C & 29 & 1,00 & 5,00 & 1,6552 & 1,07822 \\
\hline Valid N (listwise) & 29 & & & & \\
\hline
\end{tabular}


Construct validation and product moment validation using the SPSS 21 application, the results of each question item on the six indicators of multicultural education are valid, namely with an overall significant value $=0.01<0.05$ and the multicultural education indicator is reliable, the mean value for Cronbach's value is 0.75 [29, p. 125], so that all questions are valid and reliable (Table 4).

\section{Literature review}

Junior high schools need to develop indicators of multicultural education. In addition to racism, hate crimes, prejudice, and discrimination, middle-level adolescents are very aware of the need to gain an understanding of better tolerance for population diversity. Early adolescence is a period of development in which adolescents recognize the difference between how people should be treated and how they are actually treated. Education multicultural still requires reform of a comprehensive study on the whole curriculum of junior high school [42, p. 8; 37].

The multicultural problems that arise in Central Kalimantan society are due to several factors, among others: Economy, namely the Dayak ethnic group feels that they have abundant natural wealth, and tend to become government employees, while other ethnicities are resilient in entrepreneurship; Politics, namely government policies are not implemented properly so that other ethnicities fail to foster their citizens so that they can assimilate, adapt and develop areas; Law, namely the lack of justice in solving legal problems; Socio-culture, namely differences in character that tend to be something that is less understood in daily interactions; and Education, namely the curriculum that does not adopt the diversity of society and local wisdom; Educational policies that do not adopt diversity [36; 33]. Multicultural education is expected to be able to provide solutions to multicultural problems (pathologies).

The results of subsequent research, aspects of problem the principal of junior high school are First, leadership aspects of school principals have been aligned and run educatively, and managerial models, administrators, supervisors, leaders, innovators, and motivators who are disciplined and prioritize diverse backgrounds of students; Second, the planning aspect of the principal has characteristics; there are goals to be achieved, the current situation, alternative options, priorities, strategies used; Principal planning begins with a needs analysis, has clear goals and targets, has an in-depth analysis of the priorities to be achieved, which is to provide a broad actualization space for each student [25, p. 92; 54]. In essence, these various problems can be overcome by understanding and accommodating all human potential wisely through multicultural education.

The multicultural era demands that people have a world-view and work fields that are more mondial and humanistic in nature, social relations based on human, not group and sectarian considerations, this means that ideology and religion are required to put forward and be able to formulate their human and social concepts comprehensively and universally across borders of ethnicity, sect, ideology, and religion. In the multicultural era, all socioreligious organizations cannot be separated from the fields of work related to interest groups such as farmers, laborers, fishermen, and entrepreneurs. So, how does Muhammadiyah Junior High School deal with this problem? [26, p. 57; 77; 4].

Equality in rights and status will lead to justice and equality of treatment. Conflict in several parts of Indonesia has worried, which is marked by the presence of: 1) community 
groups using conflict as a mode to shed any frustrations and disappointments they feel, and 2) other community groups using conflict as a weapon to resolve the problem. One of the efforts to prevent conflict is by realizing multicultural education [41; 70]. In essence, these various problems can be overcome by understanding and accommodating all human potential wisely through multicultural education.

Most of the teachers in learning activities are still not effective and meaningful for students, this is because the professional teachers in preparing teaching material documents, mastery of the material, and mastery of learning methodologies still need to be improved and the quality of the learning process in the classroom is not optimal, especially the limited material teaching [9, p. 140].

Indonesia is a country that is rich in multicultural diversity which is combined in "Bhinneka Tunggal Ika" (national emblem) so that the attitude of social solidarity that is embedded in students is very positive because they can accept the differences in the school environment and residence (2). The historical reality, Multicultural Education Praxis is the translation of our country's, namely "Bhinneka Tunggal Ika." The principle of multiculturalism is an awareness that a nation many different components. "Bhinneka Tunggal Ika" is ignored and not properly understood, there will be undue statements, utterances, attitudes, and actions that will offend and disturb the atmosphere of diversity in the life of society and nation, resulting in social problems, unrest, and disintegration [7; 66; 15; 52].

Muhammadiyah Junior High School is a school Muhammadiyah has a big role to play by optimizing time and also good teachers. In its implementation, it is not maximal, so the need for the school, to invite back together with the family, community, and mosque in deliberating cooperation to form a complete student personality, both intellectually and emotionally [4; 69, p. 71-82]. Multicultural education is the soul of every lesson. Almost all are integrated with multicultural education. Teachers always convey the importance of tolerance in the middle of the learning process both inside and outside the classroom [54].

Muhammadiyah is an organization that is a religious movement. The ideals of Muhammadiyah which is to respect the reciprocal relationship between living things and living things together based on "Pancasila" (national principle) and the Constitution of the Republic of Indonesia year 1945 in accordance with the rules of religion to create an order of community life that maintains security and order [39, p. 2-4, p. 8-10; 71, p. 434; 1$, p. $281 ; 64 ; 51$, p. $132 ; 53]$.

Thai society has been dominated mentally, intellectually, and culturally by forces foreign to the traditional Thai spirit. Values begin to disappear and cause problems, namely morals, ethics, health, and the environment [49].

Literature character and citizenship education in Asia has often mentioned cross-cultural understanding da $\mathrm{n}$ global thinking as a model that is desired to be incorporated into the curriculum or pedagogy citizenship in schools. Thus, a teacher who has a cultural understanding or intelligence and has global insight is needed [68; 75; 24, p. 210-211; 72; 73].

In essence, multicultural education can play a role in increasing the understanding of knowledge about conflict and raising awareness to create solutions, increasing the togetherness of cultural groups so that if a conflict occurs it can be resolved effectively based on mutual respect $[70 ; 14 ; 50]$.

The nation-state needs to create new ideas about multicultural education based on local culture to foster national unity and integrity [11; 24, p. 212-2013]. Research on the multicultural education pattern of Muhammadiyah Junior High School is very important 
because multicultural education can uphold the dignity of the region while maintaining equal status as a member of the Unitary State of the Republic of Indonesia. Indonesia as a nation that has the characteristics of a pluralistic society, is a challenge in itself to remain integrated into the unity frame [39, p. 43-45; 18; 45]. Research multicultural education pattern is objective thinking of stringing concept study of theory and experience through describing areas that build multicultural education.

Multicultural content needs to be combined with effective instruction from content. Effective learning is that students interact actively among different peers culturally and between students and teachers [19]. Multicultural education is a holistic education on how to comprehensively harmonize empirical knowledge and experience that will produce a balance of the human body and spirit which includes intellectual, spiritual, and physical.

Multicultural education is a construct of several fields that exist in schools, secondary schools, society, and global [13, p. 12-13; 19; 36; 67]. The fields that construct multicultural education in this study include all fields that build multicultural education, namely: religion, gender, region, race, culture, and social class. Table 5 shows the fields of multicultural education that have been discussed by experts so far.

Table 5

The field of multicultural education

\begin{tabular}{|l|c|c|c|c|c|c|c|}
\hline Fields & Religion & Gender & Region & Race & Cultural & Social Class & Location \\
\hline Manning (1989) & $\mathrm{V}$ & $\mathrm{V}$ & $\mathrm{V}$ & $\mathrm{V}$ & & $\mathrm{V}$ & $\begin{array}{c}\text { Secondary } \\
\text { School }\end{array}$ \\
\hline Cohen \& Lotan (2004) & & $\mathrm{V}$ & $\mathrm{V}$ & $\mathrm{V}$ & & $\mathrm{V}$ & School \\
\hline Gay (2004) & & $\mathrm{V}$ & $\mathrm{V}$ & $\mathrm{V}$ & $\mathrm{V}$ & $\mathrm{V}$ & School \\
\hline Parekh (2008) & & & & & $\mathrm{V}$ & Society \\
\hline Banks (2009) & $\mathrm{V}$ & $\mathrm{V}$ & $\mathrm{V}$ & $\mathrm{V}$ & & & Society \\
\hline Banks \& Banks (2010) & & $\mathrm{V}$ & $\mathrm{V}$ & $\mathrm{V}$ & $\mathrm{V}$ & & School \\
\hline Sleeter (2010) & & $\mathrm{V}$ & $\mathrm{V}$ & $\mathrm{V}$ & $\mathrm{V}$ & & Global \\
\hline Karliani (2011) & $\mathrm{V}$ & & $\mathrm{V}$ & $\mathrm{V}$ & $\mathrm{V}$ & $\mathrm{V}$ & Society \\
\hline Alexander \& Kim (2017) & & & & & $\mathrm{V}$ & $\mathrm{V}$ & Society \\
\hline Cheon (2019) & & & $\mathrm{V}$ & & $\mathrm{V}$ & & School \\
\hline
\end{tabular}

Table 5 shows that not all fields have been discussed together into one research theme.

Research results

Palangka Raya is an administrative city with 5 sub-districts, namely Pahandut, Sabangau, Jekan Raya, Bukit Batu, and Rakumpit and has 30 villages [2]. In Palangka Raya there is a regional leadership organization Muhammadiyah Palangka Raya which only has one junior high school and one study group in class VIII with a total of 29 students.

The fields that construct multicultural education show a beautiful pattern that reflects diversity. Research from the results of the Muhammadiyah Junior High School questionnaire strengthens the study of this pattern (figure 1): 


\section{Multicultural Indicators}

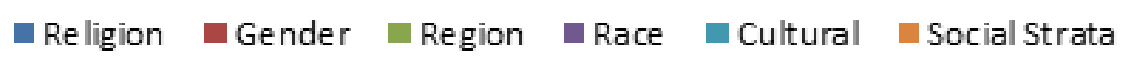

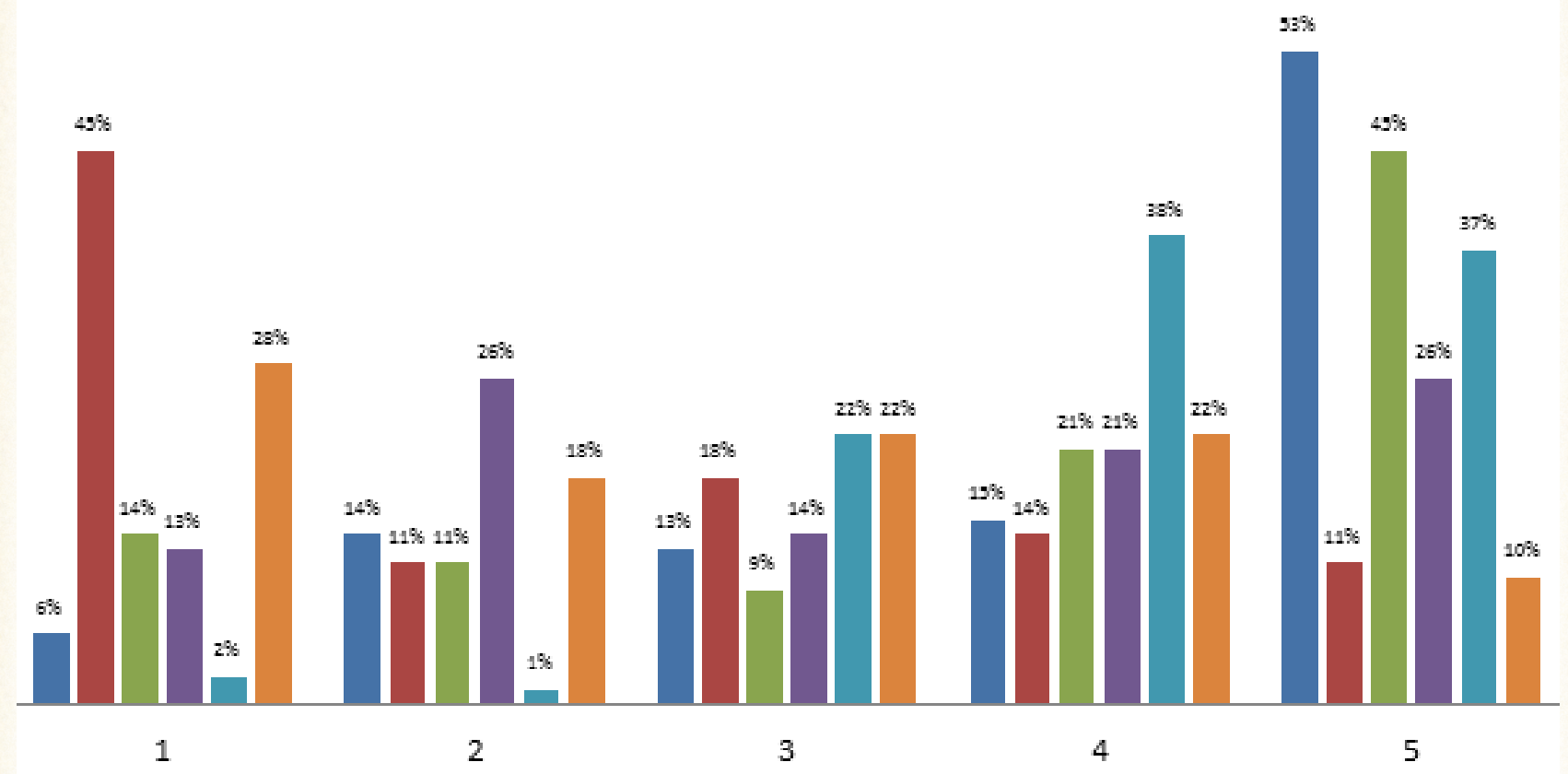

Figure 1 Research result of all fields of multicultural education for students

(Source: 54: 19)

Muhammadiyah Junior High School students build and develop multicultural education through the field of religion, namely students are strongly guided by religion as a way of learning and interacting in their daily life $(80 \%=$ Sure until Very Sure) even though there are still some who do not see religion as a guideline that must be followed in daily life-day ( $20 \%$ $=$ Less Sure until Not Sure).

Muhammadiyah Junior High School students build and develop multicultural education through gender indicators, namely feeling more comfortable hanging out with friends of different sexes but still in accordance with religious rules $157 \%=$ Sure until Very Sure). Students in socializing prefer friends of the opposite sex (43\% = Less Sure until Not Sure).

Muhammadiyah Junior High School students build and develop multicultural education through ethnic indicators, namely respecting friends who are different from their region of origin so that they are able to mingle in social relationships ( $75 \%=$ Sure until Very Sure) but there is also a tendency to feel like choosing friends from one area $(25 \%=$ Less Sure until Not Sure).

Muhammadiyah Junior High School students build and develop multicultural education through racial indicators, namely students can interact with friends who are less handsome or beautiful $(61 \%=$ Sure until Very Sure) but tend to choose friends with good physical condition (39\% = Less Sure until Not Sure).

Muhammadiyah Junior High School students build and develop multicultural education through cultural indicators, namely students value friends who are not smart and do not get along well $(97 \%=$ Sure until Very Sure) but there are still students who do not respect friends who are not smart ( $3 \%=$ Less Sure until Not Sure). 
Muhammadiyah Junior High School students build and develop multicultural education through indicators of social class, namely students who choose rich friends and parents who have positions in learning and social groups ( $54 \%=$ Sure until Very Sure) but there are still those who choose poor friends for study groups ( $46 \%=$ Less Sure until Not Sure).

But not all can implement according to the theory of multicultural education because each individual has their own thoughts and understanding of diversity $(20 \%-46 \%=$ Less Sure to Not Sure).

\section{Discussion}

Multiculturalism is an honest effort to organize a plural society into a multiculturalistic society that is both harmonious and dynamic because of the respect for human freedom and equality. People from diverse cultures often arise destructive conflicts which actually destroy the fabric of life together $[8 ; 48 ; 47$, p. 33]. Conflict is a complex problem that can be managed well if Indonesian people as individuals or groups both have knowledge of multiculturalism.

Indonesian society has a motto of unity in diversity. In fact, the slogan only occupies the cognitive awareness of society in general and does not apply caution in people's daily social life. This phenomenon is deemed necessary to immediately carry out a comprehensive study and research on multicultural education, so that it can be used as a basis and policy for education development with a pluralistic perspective $[74 ; 69$, p. 93, p. 104-105, p. 119, p. 182, and p. 193; 49]. The pluralism of Indonesian society is represented by "Bhinneka Tunggal Ika."

Multicultural Education least three things: an idea or concept, educational reform movements, and processes. Multiculturalism must be supported by a strong belief in individuality and individualism that comes out of the national macro culture which is often not supported by several ethnic and foreign communities within it [13, p. 3; 34].

The context of multicultural education in junior high schools has the aim of instilling sympathy, respect, appreciation, and empathy for adherents of different religion, gender, ethnicity, race, and culture, as well as social class and most importantly not only so that students easily understand the lessons they learn, but also to raise awareness they should always behave humanist, pluralist, and democracy $[27$, p. $30-31 ; 60 ; 20 ; 57$, p. 330]. A multicultural education curriculum must include tolerance, themes on ethnocultural and religious differences, the dangers of discrimination, conflict resolution and mediation, human rights, democracy and plurality, multiculturalism, universal humanity, and other relevant subjects. Multicultural education is learning using a holistic approach for all students regardless of anything and preparing to face obstacles that prevent many students from being able to access education [22; 34].

The holistic approach in multicultural education includes 1 ) the understanding of teachers and school principals about character education is not deep; 2) the implementation of character education is carried out through classroom learning, school culture, insertion in subjects; 3 ) the values implanted include discipline, order, kindness, benefit, and truth; 4) the inculcation of these values can be seen from the personality of students who get achievements both academically and non academically [53]. An understanding of multiculturalism can be transformed through subjects Civic Education and learning-based multiculturalism psychological impact on the development of social attitudes that foster a sense of togetherness, diversity recognizing [10]. 
Multicultural education requires cooperation and harmonious togetherness between schools, teachers, students, and parents with creates a balanced ability in terms of the implementation of ethnic, religious, racial, and inter-group diversity. Multicultural Education is a process of becoming, a process that is continuous, and not something that is immediately achieved. The purpose of multicultural education is to improve overall achievement, not just increase scores so that they become smart and good Indonesian citizens [31; 70; 34].

Multicultural education explained the culture and national identity of Indonesia. Hanifah, the results of the research, namely the social culture and geography of the Indonesian state, are faced with two important facts, first about pluralism in Indonesia and both the effects of globalization. The educational atmosphere must be ready to support this problem [32]. Indonesia is one country that has received a lot of praise from other countries regarding the management of multicultural education. Multicultural education requires a good citizen personality in schools or colleges. Multiculturalism causes challenges for society. Society develops a reflective cultural, national, and global identification and a commitment to take civic action that will make [11].

The Multicultural Education Paradigm is an activity that consciously trains the ability to respect and appreciate each other which is carried out continuously because it can cause conflict. The multicultural education paradigm is important because it will direct students to be tolerant and see inclusiveness towards the diverse realities of society in terms of culture, ethnicity, race, ethnicity, religion, and social order. The strategic function of multicultural education is to develop competencies in several standard systems to understand, evaluate, believe, and take action [40, p. 185-186; 6]. Strategy multicultural education is an education that closes to multicultural education in Indonesia.

The strategy of multicultural education Indonesia by four conceptions of multicultural education in a global context, and the implications for the curriculum. Four "ideal types" can be called: 1) respecting national cultural differences, 2) respecting international cultural differences, 3) anti-discrimination and social justice, and 4) anti-discrimination and global justice [38, p. 149; 67]. Balance and interconnectedness of contraception should be maintained in the multicultural education Muhammadiyah. Figure 2 illustrated the Grand Design of Muhammadiyah Multicultural Education Patterns in Indonesia.

Muhammadiyah influences every step in the nation's struggle cycle to avoid disintegration through the struggle for a social relationship, education, and health based on universal value and multicultural education itself. Muhammadiyah supports multicultural education because of the positive values it contains.

Multicultural education is built from patterns of religion, gender, ethnicity, race, culture, and social class in balancing the understanding and experience of human physical and spiritual diversity which includes attitudes and actions in learning and interactions in schools and communities. But not all can implement according to the theory of multicultural education because each individual has their own thoughts and understanding of diversity.

\section{Conclusion}

Multicultural education at Muhammadiyah Junior High School Palangka Raya was revealed to be able to be adopted by students so that the school still maintained the characteristics of Muhammadiyah but there were still students who were unable to adapt and construct. 


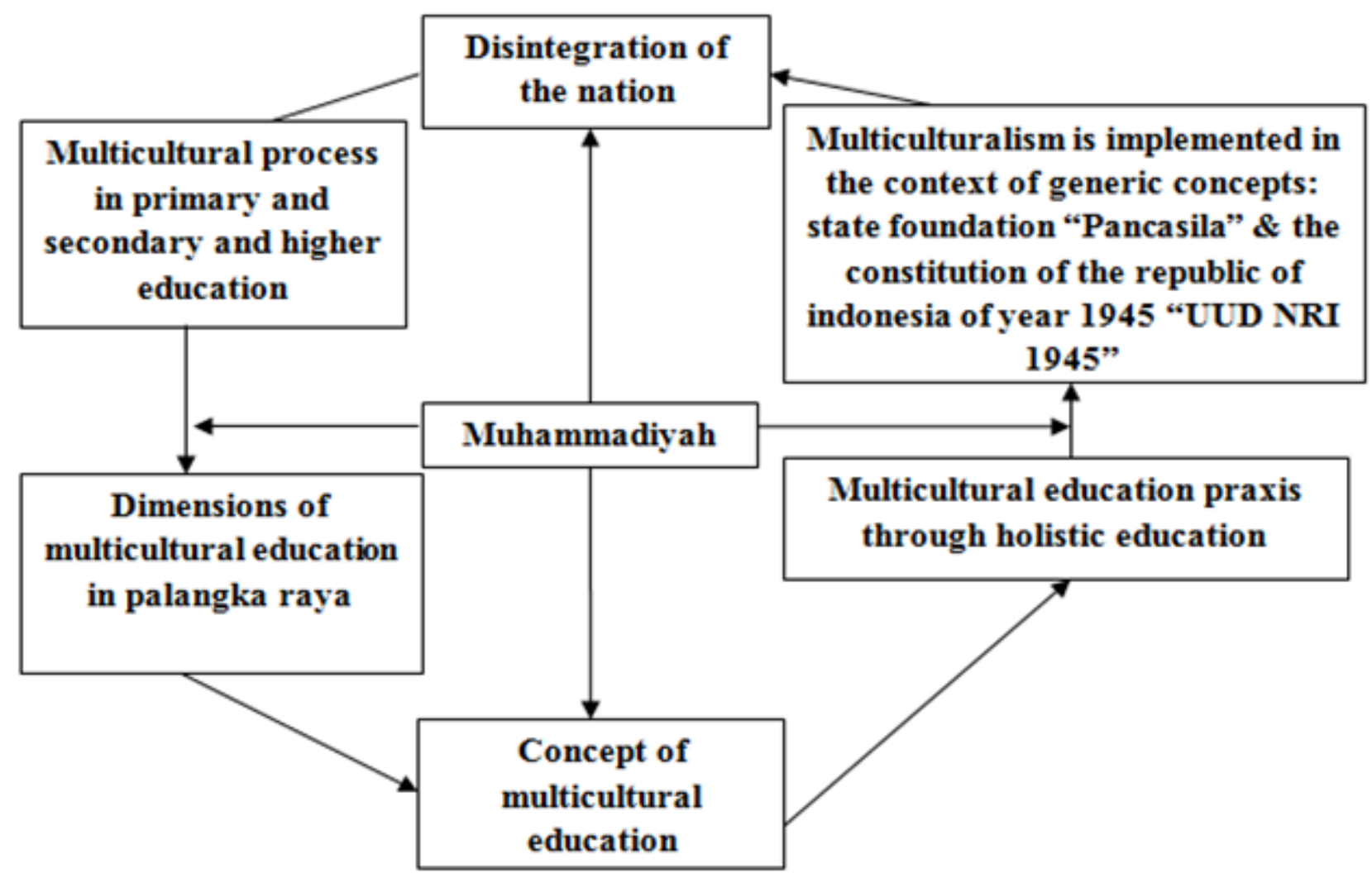

Figure 2 The grand design of muhammadiyah multicultural education patterns in Indonesia [37, p. 149; 54, p. 15]

Multicultural education patterns education Muhammadiyah Junior High School Palangka Raya, First is to give freedom to learn and social relationship of students but keep restrictions based on sex means keeping differentiate treatment on certain things, for example, a class of men and women remain separate each. Second, respecting local wisdom while remaining integrated and characterized by universal values of compassion and tolerance. For example, dancing with additional clothes that are more closed and make school more comfortable, beautiful, and healthy.

The pattern created in Muhammadiyah Junior High School, namely multicultural education, is further learning for every individual especially students, to be able to understand the differences between them and the development of respecting differences based on local wisdom.

\section{REFERENCES}

1. Abdurrahman, A. Manhaj Tarjih Muhammadiyah. Yogyakarta: Student Library, 2012.

2. Agustina, L. \& Bidaya, Z. Integration of Multicultural Education Values in the PPKn Learning Process at State Junior High School 3 Lingsar, West Lombok. Civicus, 2018, no. 6(2). pp. 54-61. https://doi.org/10.31764/civicus.v6i2.674

3. Agency of Planning, Regional Development (BAPPEDA), Palangka Raya city. Profile of Palangka Raya City Year 2018. Palangka Raya: Agency of Planning, Regional Development, Palangka Raya City, 2019.

4. Ahmad, F. KH Ahmad Dahlan's Thought About Education and Its Implementation at SMP Muhammadiyah 6 Yogyakarta in 2014/2015. Profetics, 2015, no. 16 (2). http://doi.org/10.23917/profetika.v16i2.1854

5. Alexander, N. \& Kim, H. Adequacy by Any Other Name: A Comparative Look at Educational Spending in the United States and the Republic of Korea. Journal of Education Finance, 2017, 43 (1), 65-83. Retrieved from http://www. jstor.org/stable/45093651

6. Alozie, O. E. Diversity V Multiculturalism Advantages And Disadvantages Of Workplace Diversity. International 
Journal of Scientific and Research Publications, 2020, no. 10(1). 135-140. http://doi.org/10.29322/IJSRP.10.01.2020. p9720

7. Ameny-Dixon, G. M. Why Multicultural Education is More Important in Higher Education Now than Ever: A global perspective. International Journal of Scholarly Academic Intellectual Diversity, 2004, no. 8(1), pp. 1-9. Retrieved from http://www.nationalforum.com

8. Aneta, B. Multiculturalism is an Important Characteristic of Contemporary Education. International Journal of Cognitive Research in Science, Engineering and Education, 2013, no. 1(1). Retrieved from https://cyberleninka.ru/ article/n/multiculturalism-as-important-characteristic-of-contemporary-education

9. Arief, A. Muhammadiyah Role in Global Development: Globalization and Muhammadiyah's commitment in Culture and National Character Education. Jakarta: UMJ Press, 2010.

10. Baidi. Citizenship Education Learning Based on Multiculturalism from the Perspective of Islamic Social Psychology (Study at SMP Al Islam 1 Surakarta). (Unpublished doctoral dissertation). Graduate School of Muhammadiyah Yogyakarta, 2014.

11. Banks, J. A. Diversity and Citizenship Education in Multicultural Nations. Journal of Multiculral Educational Review, 2009, no. 1(1), pp. 1-28. Retrieved from https://www.tandfonline.com/doi/citedby/10.1080/23770031. 2009.11102861?scroll=top\&needAccess=true

12. Banks, J. A. Human Rights, Diversity, and Citizenship Education. Journal The Educational Forum, 2009a, no. 73(2), 100-110. Retrieved from https://www.tandfonline.com/doi/full/ 10.1080/00131720902739478?src=recsys

13. Banks, J. A. \& Banks, C. A. M. Multicultural Education: Issues and Perspectives. The United States of America: Wiley, 2010.

14. Bećirović, S. The role of Intercultural Education in Fostering Cross-Cultural Understanding. Epiphany, 2012, no. 5 (1). http://doi.org/10.21533/epiphany.v5i1.49

15. Cahyono, H. \& Iswati, I. The Urgency of Multicultural Education as an Effort to Increase Student Appreciation of Local Cultural Wisdom. Elementary: Basic Education Scientific Journal, 2017, no. 3 (1), pp. 15-29. http://doi. org/10.32332/elementary.v3i1.771

16. Central Bureau of Statistics (BPS) \& United Nation Population Fund (UNFPA). Interest of Determinant Analysis of SP2010 Results. Jakarta: BPS \& UNFPA, 2015.

17. Cuga, C. \& Yuliadhani. The Character of the Nation with Diversity in Diversity: The Role of PPKn in Revitalizing the Values of Pancasila in the 2013 curriculum. Bandung: Citizenship Education Laboratory, Faculty of Social Science Education, University of Education Indonesia, 2013.

18. Cohen, E. G.\& Lotan, R. A. Equity in Heterogeneous Classrooms. In J. A. Banks \& C. A. M. Banks (Eds.), Handbook of Research on Multicultural Education, pp. 736-752. San Francisco: Jossey-Bass, 2004.

19. Cheon, B. K. The Diversity of Cultural Diversity: Psychological Consequences of Different Patterns of Intercultural Contact and Mixing. Asian Journal of Social Psychology, 2019, no. 22 (1), pp. 93-105. http://doi.org/10.1111/ ajsp.12321

20. Creswell. J. W. Research Design: Qualitative, Quantitative, adn Mixed Methods Approaches. (translation by Achmad Fawaid dan Rianayati Kusimini Pancasari). Yogyakarta: Pustaka Pelajar. (the original edition was published in 2014 by SAGE Publications, London, 2017.

21. Darmadi, H. Educational and Social Research Methods. Bandung: Alfabeta, 2014.

22. Davidman, L. \& Davidman, P. Multicultural Teacher Education in the State of California: The Challenge of Definition and Implementation. Teacher Education Quarterly, 1988, no. 15 (2), pp. 50-67. Available athttp://www.jstor.org/ stable/23474666

23. Dhungana, R. K. Paradoxes of Quality Education in South Asia. Corridors of Knowledge for Peace and Development (pp. 207-228, Rep.) (Aneel S., Haroon U., \& Niazi I., Eds.). Sustainable Development Policy Institute, 2020. Retrieved from https://www.pc.gov.pk/uploads/report/Corridors-of-Knowledge-for-Peace-and-Development.pdf

24. Dwiningrum, S. I. A. Developing Cultural Competenc In The Policy Of Primary Education Decentralization. Proceeding of International Seminar on Primary Education (ISPE) PGSD and DIKDAS Study Programs, Yogyakarta, Indonesia, 2013, pp. 92-98.

25. Fadjar, A. M. Muhammadiyah Education Reform is a necessity: Education as a Praxis of Humanization Aspects of Humanity as the Basis for the Renewal of the National Education Paradigm. Yogyakarta: Muhammadiyah Voice Library, 2003.

26. Gay, G. The Importance Multicultural Education (Module 1). 2004, ASCD 61 (4), pp. 30-35.

27. Geldof, D., Schrooten, M., \& Withaeckx, S. Transmigration: The Rise of Flexible Migration Strategies as Part of Superdiversity. Policy \& Politics, 2017, no. 45 (4), pp. 567-584. http://doi.org/10.1332/030557317X14972774011385

28. Hair, Jr., J.F.; Black, W.; Babin, B.; and Anderson, R. Multivariate Data Analysis. 7th ed. Uppersaddle river, New Jersey: PearsonPrentice Hall, 2010.

29. Harari, Y. N. 21 Lessons for the 21st Century. London: Jonathan Cape-Penguin Random House LLC, 2018.

30. Hanum, F.\& Rahmadonna, S. Implementation of Multicultural Learning Models in Elementary Schools in The Special Region of Yogyakarta. Journal of Educational Science Research, 2010, no. 3 (1), pp. 89-102. Availabel at https://www.neliti.com/publications/124440/implementasi-model-pembelajaran-multikultural-di-sekolah-dasar -propinsidaerahist

31. Hanifah, N. Multicultural Education Based on Local Wisdom as an Alternative Values Education in Early-Childhood Education. Advances in Social Science, Education and Humanities Research (ASSEHR), volume 58. 3rd International Conference on Early Childhood Education (ICECE-16). Atlantis Press, 2017, pp. 364-368. Retrieved from https:// download.atlantis-press.com/article /25869355.pdf 
32. Hébert, Y. Youth in Plural Cities, Multiculturalism and Citizenship: Policy Challenges and Opportunities. Foro de Educación, 2016, no. 14(20), pp. 199-230. Retrieved from https://www.redalyc.org/pdf/4475/447544536011.pdf

33. Hoon, C. Multicultural Citizenship Education in Indonesia: The Case of a Chinese Christian School. Journal of Southeast Asian Studies, 2013, no. 44(3), pp. 490-510. Retrieved from http://www.jstor.org/stable/43863217

34. Iskandar. Research Methodology. Jakarta: Gaung Persada Press, 2008.

35. Karliani, E. Development of Multicultural Communities in Increasing National Integration. Scientific Journal of Pancasila and Citizenship Education, 2011, no. 24(2), pp. 80-92. http://doi.org/10.17977/jppkn.v24i2.5488

36. Kirkham, S. Constructing Multiculturalism at School: Negotiating Tensions in Talk about Ethnic Diversity. Discourse \& Society, 2016, no. 27 (4), pp. 383-400. http://doi.org/10.1177/0957926516634548

37. Kesidou, A. Preparing Educators and Researchers for Multicultural / Intercultural Education: A Greek Perspective. In Veugelers W. (Ed.), Education for Democratic Intercultural Citizenship (pp. 148-165). LEIDEN; BOSTON: Brill. 2019. http://doi.org/10.1163/9789004411944_008

38. Maarif, A. S. et. all. Muhammadiyah's Role in Global Development. South Jakarta: UMJ Press, 2010.

39. Mahfud, C. Multicultural Education. Yogyakarta: Student Library, 2016.

40. Manning, L. M. Multicultural Education. Middle School Journal, 1989, no. 21(1), pp. 14- 16. Retrieved from http:// www.jstor.org/stable/23023929

41. Manning, L. M. Celebrating Diversity: Multicultural Education in Middle Level Schools. Columbos, Ohio: National Middle School Association, 1994.

42. Marzuki, M., Miftahuddin, M., \& Murdiono, M. Multicultural Education In Salaf Pesantren And Prevention Of Religious Radicalism In Indonesia. Jurnal Cakrawala Pendidikan, 2020, no. 39(1), pp. 12-25. http://doi.org/10.21831/ cp.v39i1.22900

43. Marrone, J. V.Cultural Assimilation As a Human Capital Formation Process: Theory and Empirical Evidence. (Unpublished doctoral dissertation). The University of Chicago, 2017.

44. Martono, N. Social Research Methods: Key Concepts. Jakarta: Rajawali Press, 2016.

45. Mikhailova, O. B. Features of Creativity and Innovation Development in Students at Secondary and High School. International Journal of Cognitive Research in Science, Engineering and Education, 2018, no. 6 (2), pp. 11-20. http:// doi.org/11.10.5937/ijcrsee1802011M

46. Molan, B. Multiculturalism, Intelligent Building a Stable and Dynamic Life Together. Jakarta: PT. Index, 2015.

47. Mostafazadeh, E., Keshtiaray, N., \& Ghulizadeh, A. Analysis of multi-cultural education concept in order to explain its components. Journal of Education and Practice, 2015, no. 6(1), pp. 1-12. Retrieved from https://eric. ed.gov/?id=EJ1083773

48. Mungmachon, M. R. Knowledge and Local Wisdom: Community Treasure. International Journal of Humanities and Social Science, 2012, no. 2(13). pp. 174-181. Retrieved from http://www.ijhssnet.com/journals/Vol_2_No_13_ July_2012/18.pdf

49. Nakaya, A. Overcoming ethnic conflict through multicultural education: The case of West Kalimantan, Indonesia. International Journal of Multicultural Education, 2018, no. 20(1), pp. 118-137. http://doi.org/10.18251/ijme. v20i1.1549

50. Nashir, H. Understanding the Muhammadiyah Ideology. Yogyakarta: Voice of Muhammadiyah, 2016.

51. Nashir, H. PP Muhammadiyah Reminds the Importance of Maintaining Diversity in Indonesia, 2019. Retrieved from https://nasional.okezone.com/read/2019/08/23/337/2095965/pp-muhammadiyah-remind-pentingnya-menjagakemajemuk-di-indonesia

52. Nurhayati, T. \& Chirzin, M. Implementation of Character Education for Students at SMP Muhammadiyah 2 Cirebon Regency. (Unpublished doctoral dissertation). Graduate UMY, 2014.

53. Nurcholis, D. Implementation of Multicultural Education Management: A Case Study at SMP Tumbuh Yogyakarta. Progresiva: Journal of Islamic Thought and Education, 2019, no. 8(2), pp. 83-91. http://doi.org/10.22219/ progresiva.v8i2.11037

54. Noor, A. F., Khunaifi, A. R., \& Supardi. Muhammadiyah Primary and Secondary and Higher Education Multicultural Perspectives in Palangka Raya, Muhammadiyah Research Grant Final Report. Palangka Raya: Muhammadiyah University of Palangka Raya, 2020.

55. Odum, H. W. American Sociology: The Story of Sociology in the United States through 1950. London: Greenwood Press, pp. 147-152, 1951.

56. Parkhouse, H., Lu C. Y., \& Massaro, V. R. Multicultural Education Professional Development: A Review of the Literature. Review of Educational Research, 2019, no. 89(3), pp. 416-458. http://doi.org/10.3102/0034654319840359

57. Parekh, B. Rethingking Multiculturalism. (Translation by C. B. Bambang Kukuh Adi). Daerah Istimewa Yogyakarta: PT Kanisius dan Yogyakarta; Institute for Multiculturalism and Pluralism Studies (IMPLUES). (the original edition was published in 2008 by Palgrave Macmillan, Hounmills, Basingstoke, Hampshir), 2018.

58. Regulation of Central Kalimantan Governor Number 22 Year 2011 concerning Procedures for Implementing Local Content Curriculum.

59. Ratna, N. K. Research Methodology: Cultural Studies and Humanities Social Sciences in General. Yogyakarta: Student Library, 2016.

60. Rahim, R. (2012). The significance of multicultural education for minority groups. Analysis: Journal of Islamic Studies, 2012, no. 12(1), pp. 161-182. Retrieved from http://ejournal.radenintan.ac.id/index.php/analysis/article/ view/634

61. Riduwan. Research Variables Measurement Scale. Bandung: Alfabeta, 2018.

62. Rothenberg, D. Multicultural education. Middle School Journal, 1993, no. 24(4), pp. 73-73. Retrieved from http:// 
www.jstor.org/stable/23023147

63. Roebroeck, E. \& Guimond, S. Schooling, Citizen-Making, and Anti-Immigrant Prejudice in France. Journal of Social and Political Psychology, 2015, no. 3(2), pp. 20-42. http://doi.org/10.5964/jspp.v3i2.391

64. Sarbini, S. (2016). Cultural Values in Muhammadiyah's Beliefs and Aspirations of Life. Tajdida: Journal of Muhammadiyah Thought and Movement, 2016, no. 14(1), pp. 47-62. Retrieved from http://journals.ums.ac.id/ index.php/tajdida/article/view/3171

65. Setyosari, P. Research and Development Methods. Jakarta: Prenadamedia Group, 2015.

66. Shofa, A. M. A. Reinterpreting Indonesian Multiculturalism in the Frame of Pancasila. JPK: Journal of Pancasila and Citizenship, 2016, no. 1(1), pp. 34-41. Retrieved from https://core.ac.uk/download/pdf/291656208.pdf

67. Sleeter, C. E. Probing Beneath Meanings of Multicultural Education. Journal of Multicultural Education Review, 2010, no. 2(1), pp. 1-24. http://doi.org/10.1080/2005615X.2010.11102867

68. Sultanova, L. Origin and Development of Multicultural Education in the USA. Comparative Professional Pedagogy, 2016, no. 6(2), pp. 49-53. Retrieved from https://eric.ed.gov/?id=EJ1124714

69. Suryana, Y. \& Rusdiana, H. A. Multicultural Education, An Effort to Strengthen National Identity (Concept-PrinciplesImplementation). Bandung: Faithful Library, 2015.

70. Somantrie, H. Conflict in a multicultural education perspective. Journal of Education and Culture, 2011, no. 17(6), pp. 660-672. http://doi.org/10.24832\%2Fjpnk.v17i6.57

71. Syamsuddin, M. D. et. all. From Muhammadiyah for Indonesia. Yogyakarta and Jakarta: Muhammadiyah Central Leadership, 2013.

72. Totok, T. The Role of Pancasila and Citizenship Education Learning in Establishing Indonesian Multicultural Society: Prospects Amid Global Cultural Pressure. PIONIR: Journal of Education, 2017, no. 6(2). http://doi.org/10.22373/ pjp.v6i2.3343

73. Van Overschelde, J., Saunders, J., \& Ash, G. Teaching is a lot more than just Showing Up to Class and Grading Assignments: Preparing Middle-Level Teachers for Longevity in The Profession. Middle School Journal, 2017, no. 48(5), pp. 28-38. Retrieved from http://www.jstor.org/stable/44841213

74. Winataputra, U. S. Multiculturalism-Bhinneka Tunggal Ika in the Perspective of Citizenship Education as a Vehicle for the Development of the Character of the Indonesian Nation. Journal of Education and Culture, 2008, no. 075(14), pp. 1009-1027. http://doi.org/10.24832/jpnk.v14i75.364

75. Wiyono, T. Implementation of Multicultural Education in Educational Praxis in Indonesia, 2014. Retrieved from http://www.pend-diy.go.id/dinas_v4/?view=v_artikel\&id=35

76. Zainuddin. Muhammadiyah Dilemma in the Multicultural Era, 2013. Retrieved from https://www.uinmalang. ac.id/r/131101/dilema-muhammadiyah-di-era-multikultural.html

\section{Information about the authors} Ady Ferdian Noor

(Palangka Raya and Yogyakarta, Indonesia)

Doctoral Student of Department of Primary Educations, Postgraduate Program

Yogyakarta State University

Assistant Professor of Department of Primary School Teacher, Faculty of Teacher Training and Education

Muhammadiyah University of Palangka Raya

E-mail: adyferdian.2018@student.uny.ac.id ORCID ID: 0000-0002-7603-8350

\section{Sonedi}

(Palangka Raya, Indonesia)

Dr in Education Management, Assistant Professor of

Department of Economic Education, Faculty of Teacher Training and Education

Muhammadiyah University of Palangka Raya E-mail: sonedi.lilik@gmail.com

ORCID ID: 0000-0002-6432-4974

\section{Mohamed Nor Azhari Azman}

(Tanjung Malim, Malaysia)

PhD in Geomatic Engineering, Associate Professor of the Department of Engineering Technology, Faculty of Technical and Vocational

Universiti Pendidikan Sultan Idris.

E-mail:mnazhari@ftv.upsi.edu.my

ORCID ID: https://orcid.org/0000-0003-1756-1990

Scopus Author ID: 36198028300

ResearcherID: A-4257-2012
A'am Rifaldi Khunaifi

(Palangka Raya, Indonesia)

Assistant Professor of Departement of Primary School Teacher Education

Faculty of Teacher Training and Education,

Muhammadiyah University of Palangka Raya

E-mail: aamrifaldi@gmail.com

ORCID ID: 0000-0002-5345-8969.

Siti Irene Astuti Dwiningrum

(Yogyakarta, Indonesia)

Professor of Departement of Primary Educations, Postgraduate Program

Yogyakarta State University

E-mail: siti ireneastuti@uny.ac.id

ORCID ID: 0000-0001-6377-6074

Scopus Author ID: 55847799900

\section{Haryanto}

(Yogyakarta, Indonesia)

Doctor in Education Technology, Associate Professor of Departement of Primary Educations, Postgraduate Program

Yogyakarta State University

E-mail: haryanto_tp@uny.ac.id 